\title{
Uji Daya Hambat Perasan Daging Buah Alpukat (Persea americana Mill.) terhadap Pertumbuhan Bakteri Staphylococcus aureus
}

\author{
${ }^{1}$ Dwi S. R. Muchyar \\ ${ }^{2}$ Damajanty H. C. Pangemanan \\ ${ }^{1}$ Aurelia S. R. Supit
}

\author{
${ }^{1}$ Program Studi Pendidikan Dokter Gigi Fakultas Kedokteran \\ ${ }^{2}$ Bagian Fisiologi Fakultas Kedokteran \\ Universitas Sam Ratulangi Manado \\ Email: dwisuci_ramadhany@yahoo.co.id
}

\begin{abstract}
To date, Staphylococcus aureus resistance to some antibiotics is still increasing inter alia the methisillin-resistant Staphylococcus aureus (MRSA). Therefore, it is necessary to find other alternative materials that could overcome this bacteria. Avocado (Persea americana Mill.) is a medicinal plant that contains antibacterial compounds such as saponins, glutathiones, flavonoids, and tannins in its fruit flesh. This study was aimed to obtain the inhibitory effect of avocado flesh on the growth of $S$. aureus. This was a true experimental study with a post test only control group design. We used Kirby-Bauer modification with paper disks. The positive control was ciprofloxacin and the negative control was aquadest. The avocado flesh was refined by using a juicer and then was filtered. Staphylococcus aureus bacteria were obtained from pure bacteria stock at Microbiology Laboratory of Pharmacy Study Program at Faculty of Mathematics and Natural Sciences, Sam Ratulangi University. The result showed that the avocado juice had an inhibitory effect on the growth of $S$. aureus. The mean diameter of inhibitory zones formed was $15.55 \mathrm{~mm}$ which was classified as a strong inhibitory effect. Conclusion: The avocado flesh had a strong inhibitory effect on the growth of Staphylococcus aureus.
\end{abstract}

Keywords: avocado flesh (Persea americana Mill.), S. aureus, inhibitory effect

\begin{abstract}
Abstrak: Resistensi bakteri Staphylococcus aureus terhadap beberapa jenis antibiotik sudah cukup tinggi. Sebagai contoh ialah methicillin-resistant Staphylococcus aureus (MRSA). Oleh karena itu perlu dicari bahan alternatif lain yang dapat mengatasi berkembang biaknya bakteri ini. Buah alpukat (Persea americana Mill.) merupakan salah satu tanaman obat yang dikenal berkhasiat sebagai antibakteri karena terdapat kandungan senyawa antibakteri pada daging buah seperti saponin, glutatin, flavonoid, dan tanin. Penelitian ini bertujuan untuk mengetahui daya hambat perasan daging buah alpukat (Persea americana Mill.) terhadap pertumbuhan bakteri $S$. aureus. Jenis penelitian ini ialah eksperimental murni dengan post test only control group design. Metode yang digunakan yaitu modifikasi Kirby-Bauer dengan kertas saring. Kontrol positif menggunakan antibakteri ciprofloxacin dan kontrol negatif menggunakan akuades. Daging buah alpukat dihaluskan dengan menggunakan juicer dan disaring. Bakteri $S$. aureus diambil dari stok bakteri murni Laboratorium Mikrobiologi Program Studi Farmasi Fakultas MIPA Universitas Sam Ratulangi. Hasil penelitian menunjukkan bahwa perasan daging buah alpukat memilki daya hambat terhadap pertumbuhan bakteri S. aureus. Diameter rerata zona hambat yang terbentuk yaitu $15,55 \mathrm{~mm}$ dan digolongkan sebagai zona hambat yang kuat. Simpulan: Perasan daging buah alpukat (Persea americana Mill.) memiliki daya hambat kuat terhadap pertumbuhan bakteri $S$. aureus.
\end{abstract}

Kata kunci: daging buah alpukat (Persea americana Mill.), S. aureus, daya hambat 
Kesehatan gigi dan mulut seringkali menjadi prioritas kedua bagi masyarakat umum, khususnya masyarakat kelas bawah. Berdasarkan Riset Kesehatan Dasar (Riskesdas) persentase penduduk yang mempunyai masalah kesehatan gigi dan mulut pada tahun 2007 mencapai 23,2\% dan pada tahun 2013 meningkat menjadi $25,9 \%{ }^{1}$

Rongga mulut merupakan salah satu bagian tubuh manusia yang paling penting, karena rongga mulut yang tidak terjaga kesehatannya dapat memicu berbagai penyakit atau kelainan pada organ lain. Salah satu pemicu munculnya berbagai penyakit di dalam mulut ialah adanya bakteri yang hidup di dalam rongga mulut. ${ }^{2}$ Bakteri dibedakan atas dua kelompok besar yaitu bakteri Gram positif dan bakteri Gram negatif. ${ }^{3}$ Terdapat juga bakteri yang bersifat aerob dan anaerob yang berjumlah lebih dari 400 spesies bakteri, salah satunya yaitu bakteri Staphylococcus aureus. ${ }^{2}$

Staphylococcus aureus merupakan mikroflora normal di dalam mulut, tetapi bisa bersifat patogen jika dipengaruhi oleh faktor predisposisi seperti perubahan kuantitas bakteri dan penurunan daya tahan tubuh pejamu. ${ }^{4}$ Saat ini angka resistensi bakteri $S$. aureus terhadap beberapa jenis antibakteri sudah cukup tinggi, salah satu contohnya ialah antibakteri golongan penisilin termasuk metisilin yang juga disebut Methicillin-resistant Staphylococcus aureus (MRSA). Resistensi disebabkan karena adanya gen mecA yang digunakan untuk mengkode protein pengikat dengan afinitas rendah. ${ }^{5}$ Prevalensi MRSA di Asia cukup tinggi yaitu mencapai $70 \%$ sedangkan di Indonesia mencapai $23,5 \%$ pada tahun $2006 .{ }^{6}$ Oleh karena itu perlu dicari bahan alternatif lain yang dapat mengatasi berkembang biaknya bakteri ini.

Terdapat berbagai cara pengobatan tradisional yang telah berkembang di Indonesia, salah satu diantaranya ialah memanfaatkan aneka ragam tanaman yang ada di Indonesia. ${ }^{7}$ Saat ini telah banyak penelitian yang dilakukan dengan menggunakan tanaman herbal alami sebagai alternatif dalam bidang pengobatan. Salah satu tanaman herbal yang dapat digunakan yaitu buah alpukat. Buah jenis ini merupakan salah satu tanaman obat yang dikenal berkhasiat sebagai antibakteri karena terdapat kandungan senyawa antibakteri pada daging buah dan daunnya seperti saponin, alkaloid, dan flavonoid, selain itu daunnya juga mengandung polifenol, dan buahnya mengandung tanin. ${ }^{8}$

Penelitian sebelumnya mengenai aktivitas senyawa dari ekstrak biji buah alpukat (Persea americana Mill.) terhadap bakteri Streptococcus mutans sudah dilakukan oleh Bujung et al. ${ }^{9}$ pada tahun 2017. Penelitian tersebut membuktikan bahwa zona hambat pada ekstrak biji alpukat sangat kuat yaitu 21,8 mm. Berdasarkan latar belakang yang dipaparkan maka penulis tertarik melakukan uji daya hambat perasan daging buah alpukat (Persea americana Mill.) terhadap pertumbuhan bakteri $S$. aureus.

\section{BAHAN DAN METODE PENELITIAN}

Jenis penelitian ini ialah eksperimental laboratorium menggunakan rancangan eksperimental murni (true experimental design) dengan post test only control group design. Penelitian ini dilaksanakan di Program Studi Pendidikan Dokter Gigi dan Laboratorium Farmasi Fakultas MIPA Universitas Sam Ratulangi Manado pada Maret - April 2018. Subjek penelitian ialah Staphylococcus aureus.

Metode pengujian yang digunakan ialah modifikasi Kirby-Bauer menggunakan kertas saring. Bakteri $S$. aureus yang disimpan di media nutrient agar (NA) diambil dari stok bakteri murni di Laboratorium Farmasi Fakultas MIPA Universitas Sam Ratulangi Manado.

Bakteri S. aureus diambil dengan jarum ose, lalu diletakkan pada nutrient agar (NA) miring dengan cara menggores. Bakteri diinkubasi dalam inkubator pada suhu $37^{\circ} \mathrm{C}$ selama $1 \times 24$ jam kemudian diambil koloninya dari media NA miring dengan jarum ose steril dan dimasukkan ke dalam media $\mathrm{NaCl} 0,9 \%$ sampai kekeruhannya sama dengan standar McFarland.

Selanjutnya kertas saring pertama dicelupkan ke dalam perasan daging buah 
alpukat konsentrasi 100\% kemudian diletakkan di atas media MHA yang sudah ditanamkan bakteri. Kertas saring kedua dicelupkan dengan kontrol positif yaitu ciprofloxacin yang sudah dilarutkan dengan akuades kemudian cawan Petri diinkubasi dalam suhu $37^{\circ} \mathrm{C}$ selama $1 \times 24$ jam. Pengamatan dilakukan setelah 24 jam masa inkubasi. Zona hambat yang terbentuk di sekitar kertas saring diukur diameter vertikal dan diameter horizontal dalam satuan millimeter $(\mathrm{mm})$ menggunakan jangka sorong.
Diameter zona hambat dapat diukur dengan rumus: $\frac{D_{\mathrm{v}}+\mathrm{D}_{\mathrm{H}}}{2}$

Gambar 1 menunjukkan pengukuran diameter zona hambat.

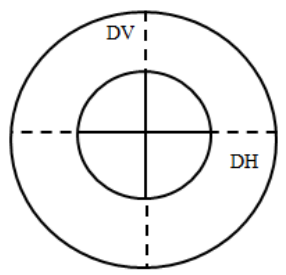

Gambar 1 . Pengukuran diameter zona hambat $\mathrm{D}_{\mathrm{v}}$ : Diameter vertikal, $\mathrm{D}_{\mathrm{H}}$ : Diameter horizontal

Tabel 1. Hasil pengukuran rerata diameter zona hambat bakteri Staphylococcus aureus

\begin{tabular}{cccc}
\hline Pengulangan & $\begin{array}{c}\text { Derasan daging buah alpukat } \\
\text { (Persea americana Mill) }\end{array}$ & $\begin{array}{c}\text { Kontrol positif } \\
\text { (ciprofloxacin) }\end{array}$ & $\begin{array}{c}\text { Kontrol negatif } \\
\text { (akuades) }\end{array}$ \\
\hline 1 & 16,25 & 39,75 & 0 \\
2 & 14,5 & 41,35 & 0 \\
3 & 15,85 & 42 & 0 \\
4 & 17,85 & 39,65 & 0 \\
5 & 13,3 & 41,05 & 0 \\
Rerata & 15,55 & 40,76 & 0 \\
\hline
\end{tabular}

\section{BAHASAN}

Penelitian ini merupakan uji eksperimental laboratorium untuk mengetahui adanya efek aktivitas antibakteri dari perasan daging buah alpukat (Persea americana Mill.) terhadap pertumbuhan bakteri $S$. aureus. Penelitian ini dilakukan dengan cara membiakkan bakteri $S$. aureus dalam media Muller-Hinton Agar (MHA) disertai dengan peletakan kertas saring yang yang sudah direndam selama 1 jam. Peletakan kertas saring yang direndam pada perasan daging buah alpukat, peletakan kertas saring yang direndam dalam antibakteri ciprofloxacin $32 \mu \mathrm{g} / \mathrm{ml}$ sebagai kontrol positif, serta peletakan kertas saring yang direndam dalam akuades sebagai kontrol negatif, lalu diinkubasi selama 1x24 jam.

Berdasarkan hasil pengamatan terhadap lima cawan Petri terlihat adanya zona hambat yang terbentuk di sekitar kertas saring yang diberi perasan daging buah alpukat. Rerata diameter zona hambat yang terbentuk pada perasan daging buah alpukat setelah lima kali pengulangan yaitu 15,55 $\mathrm{mm}$. Rerata diameter zona hambat ini termasuk dalam kategori zona hambat kuat menurut klasifikasi David dan Stout. ${ }^{10,11}$

Perbandingan diameter hasil perasan daging buah alpukat dengan diameter antibakteri ciprofloxacin menunjukkan bahwa kertas saring yang telah berisi perasan daging buah alpukat memiliki diameter zona hambat yang lebih kecil daripada kertas saring yang berisi obat antibakteri ciprofloxacin, sedangkan kertas saring yang berisi akuades tidak menunjukkan adanya zona hambat. Hasil diameter perasan daging buah alpukat lebih kecil dari antibakteri ciprofloxacin karena dipengaruhi oleh konsentrasi hambat minimal ciprofloxacin yang telah diketahui yaitu 32 $\mu \mathrm{g} / \mu \mathrm{l}$, sedangkan untuk kemampuan perasan daging buah alpukat belum diketahui 
konsentrasi yang sesuai untuk menghambat pertumbuhan bakteri S. aureus.

Uji daya hambat perasan daging buah alpukat terhadap pertumbuhan bakteri $S$, aureus merupakan penelitian yang belum pernah dilakukan sebelumnya. Penelitian sebelumnya yaitu uji daya hambat ekstrak pada biji, buah, dan daun buah alpukat (Persea americana Mill.) terhadap bakteri penyebab infeksi lainnya. Penelitian uji daya hambat ekstrak etanol biji buah alpukat (Persea americana Mill.) terhadap pertumbuhan bakteri Escherichia coli dan $S$. aureus yang dilakukan oleh Anggrella et al. ${ }^{12}$ menunjukkan adanya zona hambat antibakteri masing-masing $14,9 \mathrm{~mm}$ dan $17,3 \mathrm{~mm}$ yang termasuk dalam kategori kuat. Uji daya hambat ekstrak buah alpukat (Persea americana Mill.) terhadap pertumbuhan $S$. aureus dan Staphylococcus epidermis yang dilakukan oleh $\mathrm{Azmi}^{13}$ menunjukkan adanya zona hambat antibakteri sebesar 14,5 mm dan 14,3 mm yang termasuk dalam kategori kuat. Uji daya hambat ekstrak daun alpukat (Persea americana Mill.) terhadap pertumbuhan $S$. aureus yang dilakukan oleh Muthmainnah ${ }^{14}$ menunjukkan adanya zona hambat antibakteri sebesar 15,1 mm yang termasuk dalam kategori kuat dan uji daya hambat ekstrak etil asetat daun alpukat (Persea americana Mill.) terhadap pertumbuhan $S$. aureus yang dilakukan oleh Andriani ${ }^{15}$ menunjukkan adanya zona hambat antibakteri sebesar $9,2 \mathrm{~mm}$ yang termasuk dalam kategori sedang. Penelitian sebelumnya juga pernah dilakukan menggunakan jenis buah yang sama tetapi menggunakan bakteri serta cara pengambilan variabel penelitian yang berbeda oleh Bujung et al. ${ }^{9}$ yaitu mengenai uji daya hambat ekstrak biji buah alpukat (Persea americana Mill.) terhadap pertumbuhan Streptococcus mutans menunjukkan adanya zona hambat antibakteri sebesar 21,8 $\mathrm{mm}$ yang termasuk dalam kategori sangat kuat. Hasil penelitian ini membuktikan bahwa perasan daging buah alpukat (Persea americana Mill.) terhadap pertumbuhan bakteri $S$. aureus menunjukkan adanya zona hambat antibakteri sebesar $15,55 \mathrm{~mm}$ yang termasuk dalam kategori kuat. Zona hambat perasan daging buah alpukat lebih kecil dibandingkan ekstrak biji buah alpukat karena adanya kandungan senyawa kimia pada biji buah alpukat yang tidak terdapat pada daging buah alpukat) yaitu alkaloid dan triterpenoid. Kandungan senyawa kimia alkaloid dan triterpenoid memiliki mekanisme kerja sebagai antibakteri. Selain itu, ekstrak biji buah alpukat memiliki zona hambat yang lebih besar dibandingkan perasan daging buah alpukat karena adanya senyawa kimia lain yang ditambahkan pada pembuatan ekstrak biji buah alpukat seperti pelarut etanol $96 \%$ yang dapat memengaruhi zona hambat ekstrak biji buah alpukat. ${ }^{9}$

Antibakteri ciprofloxacin dijadikan sebagai kontrol positif karena ciprofloxacin merupakan antibakteri pilihan yang memiliki kepekaan terhadap semua bakteri diantaranya bakteri gram positif dan bakteri gram negatif. Pada tahun 1980, dengan penambahan atom fluor pada molekul kuinolon dihasilkan ciprofloxacin yang merupakan generasi pertama fluorokuinolon atau generasi kedua dari kuinolon. Obat ini mempunyai aktivitas terhadap Gram positif yang tinggi dan lebih kuat melawan Enterobacteriaceae dan mempunyai spektrum lebih lebar. Mekanisme kerja dari fluorokuinolon termasuk ciprofloxacin berbeda dengan antibakteri lainnya seperti beta laktam, makrolida, tetrasiklin atau aminoglikosida. Oleh karena itu, organisme resisten terhadap berbagai antibakteri tersebut dapat masih sensitif terhadap ciprofloxacin. ${ }^{16,17}$

Penelitian ini menunjukkan bahwa perasan daging buah alpukat (Persea americana Mill.) memiliki daya hambat terhadap pertumbuhan bakteri Staphylococcus aureus, namun zona hambatnya lebih kecil dibandingkan dengan antibakteri ciprofloxacin, dan juga menunjukkan adanya senyawa antibakteri pada daging buah alpukat (Persea americana Mill.).

\section{SIMPULAN}

Dari hasil penelitian dapat disimpulkan bahwa perasan daging buah alpukat (Persea americana Mill.) memiliki daya 
hambat kuat terhadap pertumbuhan bakteri Staphylococcus aureus.

\section{SARAN}

Diharapkan dapat dilakukan penelitian lebih lanjut mengenai uji daya hambat kadar minimum perasan daging buah alpukat (Persea americana Mill.) terhadap pertumbuhan bakteri Staphylococcus aureus dengan menggunakan metode konsentrasi bertingkat.

Diharapkan agar dilakukan penelitian lanjut mengenai perasan daging buah alpukat (Persea americana Mill.) untuk mengetahui kandungan senyawa kimianya melalui metode skrining fitokimia.

\section{DAFTAR PUSTAKA}

1. Badan Penelitian dan Pengembangan Kesehatan. Riset kesehatan dasar Riskesdas 2013. Jakarta: Kementerian Kesehatan RI, 2013.

2. Sariningsih E. Gigi Busuk dan Poket Periodontal sebagai Fokus Infeksi. Jakarta: PT Gramedia; 2014. h. 20,37.

3. Pelezar JM, Chan ECS. Dasar-dasar Mikrobiologi. Jakarta: UI-PRESS, 1998; p. 563.

4. Nadhila NF. The activity of antibacterial agent of honey againts Staphylococcus aureus. J Majority. 2014;3(7):94-101.

5. Irianto K. Mikrobiologi Medis. Bandung: Alfabeta, 2013; p. 285.

6. Affandi A, Andrini F, Lesmana SD. Penentuan konsentrasi hambat minimal dan konsentasi bunuh minimal larutan povidon iodium $10 \%$ terhadap Staphylococcus aureus resisten metisilin (MRSA) dan Staphylococcus aureus sensitif metisilin (MSSA). JIK 2009;3(1):14-9.

7. Delimartha S. Atlas Tumbuhan Obat Indonesia Jilid 4. Jakarta: Puspa Swara, 2006; p. iii-iv.

8. Ernawati, Sari K. Kandungan senyawa kimia dan aktivitas antibakteri ekstrak kulit buah alpukat (Persea americana $P$. Mill) terhadap bakteri Vibrio alginolyticus. Kajian Veteriner. 2015; 3(2):203-11.

9. Bujung AH, Homenta H, Khoman JA. Uji daya hambat ekstrak biji buah alpukat
(Persea americana Mill.) terhadap pertumbuhan Streptococcus mutans. eG. 2017;5(2):112- 6.

10. Mpila DA, Fatimawali, Wiyono WI. Uji aktivitas antibakteri ekstrak etanol daun mayana (Coleus atropurpureus [L] Benth) terhadap Staphylococcus aureus, Escherichia coli, dan Pseudomonas aeruginosa secara in vitro; Manado; Universitas Sam Ratulangi; 2012.

11. Kaawoan PT, Abijulu J, Siagian KV. Uji daya hambat ekstrak buah pala (Myristica fragrans Houtt) terhadap bakteri penyebab periodontitis Porphyromonas gingivalis secara in vitro. eG. 2016;4(2):111-4.

12. Anggrella DP, Waluyo J, Wahyuni D. Perbedaan daya hambat ekstrak etanol biji alpukat (Persea americana Mill.) terhadap pertumbuhan bakteri Escherichia coli dengan Staphylococcus aureus. Artikel Ilmiah Hasil Penelitian Mahasiswa 2014:1 - 5.

13. Azmi LA. Daya hambat ekstrak buah alpukat (Persea americana Mill.) terhadap pertumbuhan Staphylococcus aureus dan Staphylococcus epidermis [Skripsi]. Semarang: Program Studi DIV Analisis Kesehatan Fakultas Ilmu Keperawatan dan Kesehatan Universitas Muhammadiyah; 2016.

14. Muthmainnah B. Uji daya hambat ekstrak daun alpukat (Persea americana Mill.) terhadap pertumbuhan bakteri Staphylococcus aureus. Makassar: Program Studi DIII Farmasi STIKES Nani Hasanuddin; 2016.

15. Andriani CR, Oesman F, Nursanty R. Uji zona hambat ekstrak etil asetat daun alpukat (Persea americana Mill.) terhadap pertumbuhan bakteri Staphylococcus aureus. Jurnal Kedokteran Syiah Kuala. 2016;16(1):1-5.

16. Raini M. Antibiotik golongan fluorokuinolon: manfaat dan kerugian. Media Litbangkes. 2016;26(3):163-74.

17. Gunawan SG, Setiabudy R, Nafrialdi. Farmakologi dan Terapi (5th ed). Jakarta: Departemen Farmakologi dan Terapeutik Fakultas Kedokteran Universitas Indonesia, 2007; p. 718-9. 